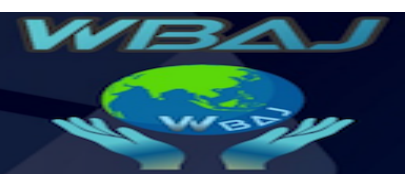

Volume 1 Issue 1, Juni 2019

http://ejournal.unsub.ac.id/index.php/bisnis

\title{
Pengaruh Kualitas Pelayanan Terhadap Kepuasan Nasabah Pt.Bank Mandiri Republik Indonesia Unit Tanjung Siang
}

\author{
Deddy Suhardi ${ }^{1}$ \\ Fakultas Ilmu Administrasi Universitas Subang \\ deddysuhardi58@gmail.com \\ Silvy Sondari Gadzali² \\ Fakultas Ilmu Administrasi Universitas Subang \\ silvysondari.gadzali@gmail.com
}

\begin{abstract}
Abstrak
Di era globalisasi dalam kegiatan ekonomi, peranan dunia usaha khususnya dalam sektor finansial dan perbankan semakin menampakan perubahan yang sangat pesat. Dalam dunia perbankan yang menjadi sorotan utama buka hanya produk dan jasa, kualitas pelayanan merupakan bagian penting yang perlu dimiliki oleh pelaku usaha perbankan. Dalam rangka memuaskan nasabah, sebuah bank harus berusaha untuk meningkatkan kualitas harapan nasabah. Berdasarkan hasil penelitian diketahui tingkat kualitas pelayanan di PT. BMRI unit Tanjung Siang terhadap nasabahnya cukup tinggi. Tingkat kepuasan nasabah di PT. BMRI unit Tanjung Siang cukup tinggi. Namun Pengaruh kualitas pelayanan secara variabel $x$ tunggal (parsial) terhadap kepuasan nasabah di PT. BMRI unit Tanjung Siang tidak memiliki pengaruh namun bila kualitas pelayanan digabungkan dengan variabel $x$ (lainnya) memiliki pengaruh terhadap kepuasan nasabah.
\end{abstract}

Kata kunci: Kualtas pelayanan

\section{Abstract}

In the era of globalization in economic activities, the role of the business world, especially in the financial and banking sectors, is increasingly showing rapid changes. In the banking world, which is the main focus open only to products and services, the quality of services is an important part that needs to be owned by banking businesses. In order to satisfy customers, a bank must strive to improve the quality of customer expectations. Based on the results of the study note the level of service quality at at PT. Bank Mandiri Republik Indonesia (PT.BMRI) 


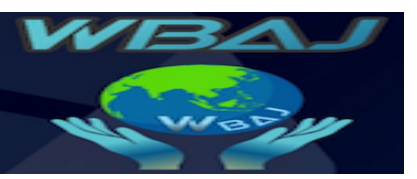

Volume 1 Issue 1, Juni 2019

http://ejournal.unsub.ac.id/index.php/bisnis

Unit Tanjungsiang for its customers is quite high. The level of customer satisfaction at at PT. Bank Mandiri Republik Indonesia (PT.BMRI) Unit Tanjungsiang is quite high. The effect of service quality is variable $x$ single (partial) on customer satisfaction at at PT. Bank Mandiri Republik Indonesia (PT.BMRI) Unit Tanjungsiang has no influence but if service quality is combined with $x$ (other) variables it has an influence on customer satisfaction.

Keywords : The quality of services

\section{Pendahuluan}

Dalam dunia perbankan yang menjadi sorotan utama buka hanya produk dan jasa, kualitas pelayanan merupakan bagian penting yang perlu dimiliki oleh pelaku usaha perbankan. Para pelaku bisinis yang sering menggunakan jasa perbankan untuk kelangsungan usahanya, kecepatan, keramahan dan kualitas pelayanan itu semua akan selalu melekat dalam usaha perbankan. Kunci utama untuk tetap bertahan dalam usaha dunia perbankan adalah komitmen agar tetap mempertahankan kualitas pelalayanan yang telah ada atau sudah berjalan juga konsisten untuk selalu berinovasi dalam memberikan kualitas produk dan kualitas pelayanan terbaik. Kini semakin disadari banyak pesaing di industri perbankan di Indonesia bukan hanya pelaku bisnis dalam negeri saja akan tetapi luar negeri pun banyak yang sudah berkompetitif dalam industri perbankan. Bukan hanya persaingan produk dan jasa yang menjadi point utama, kepuasan nasabah juga merupakan aspek vital dalam mempertahankan bisnis dan memenangkan persaingan, jika kita perhatikan produk yang sama pada perbankan itu sudah biasa terjadi. Bertahan tidaknya suatu perusahaan ditentukan oleh kemampuan perusahaan itu sendiri. Bagaimana bisa memberikan kualitas pelayanan yang baik bagi nasabah.

Dalam rangka memuaskan nasabah, sebuah bank harus berusaha untuk meningkatkan kualitas harapan nasabah. Di sinilah perlunya subah perusahaan perbankan meningkatkan kualitas pelayanannya agar nasabah bisa dipertahankan sehingga tetap setia untuk tidak berpindah ke bank lain. usaha untuk cara pemuasan nasabah dapat dilakukan dengan menafsirkan kebutuhan dan keinginan nasabah baik yang bersifat kualitatif maupun kuantitatif kemudian diikuti dengan kegiatan yang membantu pemuasan kebutuhan tersebut. Banyak aspek yang perlu dipelajari lebih dalam untuk mengetahui berbagai kebutuhan yang nasabah butuhkan, perlu adanya pendekatan kepada nasabah awareness dan know your costumer, karena keinginan setiap orang berbeda-beda begitu pun kebutuhan dalam transaksi perbankan. Perubahan jaman di era digital seperti ini sangat mudah untuk mengetahui tingkat kepuasan nasabah dan kualitas pelayanan yang diberikan oleh perusahaan dalam melayani nasabah. Berbagai produk pun diciptakan dengan mengguanakan aplikasi pada media elektronik seperti aplikasi di ponsel, itu juga membantu nasabah untuk bertransaksi secara kompleks. Tetapi ada saja nasabah yang selalu berkunjung ke bank dan melakukan transaksi langsung antri di teller per harinya. 


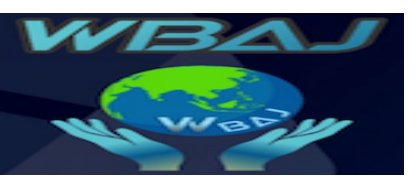

Volume 1 Issue 1, Juni 2019

http://ejournal.unsub.ac.id/index.php/bisnis

Begitu banyak kemudahan dan produk yang ditawarkan oleh pelaku bisnis perbankan, sangat membantu mempersingkat waktu tetapi hal itu menjadi tolak ukur bagi kualitas pelayanan yang diberikan (efesien), sangat banyak bantu yang mempermudah nasabah ada juga banyak permasalahan yang timbul disaat pelayanan langsung di teller dengan antrian yang selalu ramai dengan posisi pelayanan berdiri ataupun pelayanan menggunakan ponsel, dari situlah peran karyawan perbankan dalam memberikan kualitas pelayanan dengan pelayanan yang cepat, akurat dan dapat memuaskan nasabah agar permasalahan bisa terselesaikan dan nasabah merasakan pengalaman yang menyenangkan telah menggunakan jasa perusahaan berikan. Pelayanan yang diberikan harus membuat nasabah merasa puas, Kotler (2015:46) menyatakan bahwa: Kepuasan adalah tingkat perasaan seseorang setelah membandingkan kinerja atau hasil yang ia rasakan dibandingkan dengan harapanya. Dalam mengevaluasi kepuasaan nasabah terhadap produk jasa dari perusahaan tersebut, nasabah pada umumnya mengacu pada berbagai faktor atau dimensi. Jadi tingkat kepuasan merupakan fungsi perbedaan antara kinerja yang dirasakan oleh harapan. Jika kinerja yang dirasakan sesuai dengan harapan maka nasabah akan merasa puas. Harapan nasabah diyakini mempunyai peran yang besar dalam menentukan kepuasan nasabah. Harapan nasabah merupakan keyakinan nasabah sebelum mencoba atau membeli suatu produk. Yang dijadikan landasan atau acuan dalam menilai suatu produk atau jasa, dalam mengevaluasi nasabah menggunakan harapanya sebagai acuan.bank sebagai lembaga perantara keuangan. Disamping harus tetap menjaga kepercayaan masyarakat dengan menjamin tingkat likuiditas pun harus beroperasi secara efektif dan efisien guna mencapai tingkat rentabilitas (keuntungan) yang memadai. Tingkat kepuasan nasabah pun diukur dari loyal tidak-nya nasabah tersebut akan pelayanan yang diberikan selama mereka bertransaksi di bank. Baik tidak-nya pelayanan ditentukan juga dari kinerja karyawan dalam memberikan pelayanan, jika nasaba merasa puas maka mereka juga tidak akan segan untuk selalu datang kebang guna melakukan transaksi dan menggunakan jasa bank yang lainya.

Kepuasan nasabah tercipta karena kualitas pelayanan yang baik. Untuk mengukur sebuah kualitas pelayanan dapat diukur menggunakan dimensi-dimensi mengenai kualitas pelayanan. Pasuraman dalam tjiptono (2014:347); mengidentifikasi 5 dimensi yaitu relibilitas, daya tanggap, jaminan, empati dan bukti fisik. Dalam dunia perbankan Nasional, saat ini sedang mengalami digitalisasi dalam hal pelayanan. Seperti yang kita ketahui bersama, kemajuan teknologi (gadget) berimbas pada kemajuan dalam bidang perbankan. Digitalisasi pelayanan perbankan dianggap lebih efektif dan efisien karena dapat diakses tanpa perlu datang ke bank, untuk daerah urban penggunaan teknologi digital sudah sangat lumrah bahkan masif di daerah perkotaan. Dalam penggunaan teknologi digital pelayanan perbankan belum seluruh bank menggunakan teknologi tersebut. penggunaan teknologi ini bisa mempengaruhi pada daya tarik nasabah untuk menggunakan pelayanan suatu bank. Tjiptono mengungkapkan indikator dari kualitas pelayanan adalah tangible, reability, assurance, responsivennes. Sedangkan kepuasan nasabah menurut Kotler (2015:108) memiliki 
dimensi yaitu (1) Kebutuhan dan keinginan nasabah (2) pelayanan yang diharapkan nasabah (3) kinerja yang dirasakan. Bank Mandiri (Persero) TBK Unit Tanjungsiang yang kemudian akan disebut PT. Bank Mandiri Republik Indonesia (PT.BMRI) Unit Tanjungsiang merupakan unit bank yang berada di kecamatan Tanjungsiang. Bank Mandiri berkomitmen membangun hubungan jangka panjang yang didasari atas kepercayaan baik dengan nasabah bisnis maupun perseorangan. Kami melayani seluruh nasabah dengan standar layanan internasional melalui penyediaan solusi keuangan yang inovatif. Kami ingin dikenal karena kinerja, sumber daya manusia dan kerjasama tim yang terbaik. Begitupun PT. Bank Mandiri Republik Indonesia (PT.BMRI) Unit Tanjung Siang selalu berkomitmen untuk memberikan layanan terbaik bagi nasabahnya.

Setelah peneliti melakukan observasi di PT. Bank Mandiri Republik Indonesia (PT.BMRI) Unit Tanjungsiang, peneliti mengidentifikasi adanya penurunan jumlah transaksi yang ada pada PT. Bank Mandiri Republik Indonesia (PT.BMRI) Unit Tanjungsiang, Permasalahan lain yang penulis amati adalah rendanya penggunaan produk layanan teknologi digital dalam pelayanan nasabah di PT. Bank Mandiri Republik Indonesia (PT.BMRI) Unit Tanjungsiang oleh nasabah, hal ini dapat terjadi karena kurangnya informasi atau banner-banner yang memperlihatkan tentang panduan dalam mengunakan produk layanan digital PT. Bank Mandiri Republik Indonesia (PT.BMRI) sehingga pengetahuan nasabah tentang produk layanan teknologi digital PT. Bank Mandiri Republik Indonesia (PT.BMRI) Unit Tanjungsiang yang tersedia kurang dipahami dan dimengerti nasabah. Dari pemaparan diatas penulis menemukan beberapa indikator permasalahan terkait kualitas pelayanan PT. Bank Mandiri Republik Indonesia (PT.BMRI) Unit Tanjungsiang yang antara lain : kurangya jumlah karyawan frontliner PT. Bank Mandiri Republik Indonesia (PT.BMRI) Unit Tanjungsiang yang melayani nasabah, menyebabkan antrian yang cukup panjang sehingga nasabah merasa tidak puas akan pelayanan PT. Bank Mandiri Republik Indonesia (PT.BMRI) Unit Tanjungsiang; serta kurangnya fasilitas pendukung informasi layanan PT. Bank Mandiri Republik Indonesia (PT.BMRI), menyebabkan nasabah kekurangan informasi mengenai cara penggunaan produk layanan PT. Bank Mandiri Republik Indonesia (PT.BMRI), sehingga penggunaan produk layanan PT. Bank Mandiri Republik Indonesia (PT.BMRI) di Unit Tanjungsiang masih rendah

\section{Kerangka Teori}

\section{Pengertian Jasa}

Jasa merupakan suatu kinerja penampilan, tidak berwujud dan cepat hilang, lebih dapat dirasakan dari pada dimiliki, serta nasabah lebih dapat berpartisipasi aktif dalam proses mengkonsumsi jasa tersebut. kondisi cepat lambatnya pertumbuhan jasa tergantung pada penilaian nasabah terhadap kinerja yang ditawarkan oleh pihak produsen. Menurut Rismiati (2001:270) menyatakan bahwa : "Jasa didefinisikan sebagai setiap kegiatan atau manfaat yang ditawarkan oleh satu pihak kepada pihak lain dan merupakan barang tidak berwujud (intangble) serta tidak berakibat pada kepemilikan 


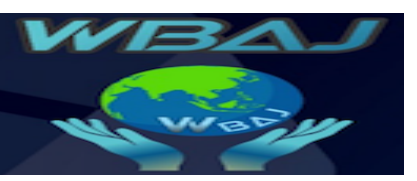

Volume 1 Issue 1, Juni 2019

http://ejournal.unsub.ac.id/index.php/bisnis

akan sesuatu.". Suatu perusahaan yang bergerak dalam menawarkan sesuatu pasti membutuhkan jasa pelayanan. Kotler (2015:55) berpendapat bahwa "Jasa adalah setiap tindakan atau perbuatan yang ditawarkan oleh pihak lain yang pada dasarnya bersifat tidak berwujud (Intangibless) dan tidak menghasilkan kepemilikan sesuatu. Sedangkan Tjiptono berpendapat bahwa jasa sebagai aktivitas, manfaat atau kepuasan yang ditawarkan untuk dijual. Berdasarkan kedua definisi tersebut, dapat diartikan bahwa di dalam jasa selalu ada aspek interaksi antara pihak nasabah dan pihak pemberi jasa, meskipun pihak-pihak yang terlibat tidak selalu menyadarinya. Jasa bukan merupakan barang tetapi suatu proses aktivitas yang tidak berwujud." Beberapa karakteristik jasa menurut Kotler (2015:87) diuraikan sebagai berikut.

1) Tidak berwujud (Intangibles)

2) Jasa berbeda dengan barang, jika barang merupakan suatu objek, alat atau usaha maka jasa adalah sebuah perbuatan, kinerja atau usaha.

3) Tidak terpisahkan (Inseparability)

4) Barang biasanya diproduksi, kemudian dijual lalu dikonsumsi. Sedangkan jasa bisanya dijual terlebih dahulu baru kemudian diproduksi dan dikonsumsi secara bersamaan.

5) Bervariasi (Variability)

6) Jasa bersifat sangat variatif karena merupakan nonstandardize output artinya banyak variasi bentuk, kualitas dan jenis tergantung pada siapa, kapan dan di mana saja tersebut dihasilkan.

7) Mudah lenyap (Perishability)

8) Jasa merupakan komoditas tidak tahan lama dan tidak dapat disimpan.

9) Berdasarkan pemaparan diatas maka jasa adalah kegiatan yang ditawarkan oleh satu pihak kepada pihak lain dalam bentuk barang tidak berwujud (intangble) serta tidak berakibat pada kepemilikan akan sesuatu

\section{Pengertian Kualitas, Pelayanan dan Kualitas Pelayanan}

Kualitas adalah sebuah kata yang bagi penyedia jasa adalah sesuatu yang harus dikerjakan dengan baik. Tjiptono mendefinisikan "kualitas merupakan suatu kondisi dinamis yang berhubungan dengan produk, jasa, manusia, proses dan lingkungannya yang memenuhi atau melebihi harapan". Kualitas merupakan strategi bisnis yang menghasilkan barang atau jasa guna memenuhi kebutuhan dan kepuasan nasabah, secara eksplisit dan implisit. Sedangkan Kotler (2015:87) menyatakan bahwa "Kualitas adalah seluruh ciri serta sifat suatu produk pelayanan yang berpengaruh pada kemampuan untuk memuaskan kebutuhan yang dinyatakan atau tersirat. Ini jelas merupakan definisi kualitas yang berpusat pada nasabah, seorang produsen dapat memberikan kualitas apabila produk atau pelayanan yang diberikan dapat memenuhi atau melennihi harapan nasabah. Berdasarkan pengertian dari kualitas tersebut, dapat diartikan bahwa kualitas harus merupakan suatu pola yang dapat menginterpretasikan tuntutan dan kebutuhan pasar nasabah dalam suatu proses manajemen dan proses produksi barang atau jasa secara terus menerus sehingga memenuhi persepsi kualitas 


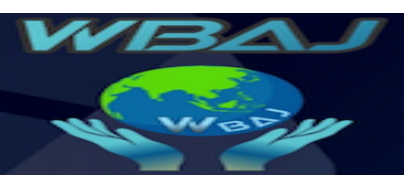

Volume 1 Issue 1, Juni 2019

http://ejournal.unsub.ac.id/index.php/bisnis

pasar nasabah tersebut. Selanjutnya Kualitas menurut Pasolong $(2017 ; 132)$ menyatakan bahwa : "kualitas adalah 1) kesesuaian dengan persyaratan/tuntutan; 2) kecocokan pemakaian 3) perbaikan atau penyempurnaan keberlanjutan; 4) bebas dari kerusakan; 5) pemenuhan kebutuhan nasabah semenjak awal dan setiap saat; 6) melakukan sesuatu secara benar sejak awal; 7) sesuatu yang bisa membahagiakan nasabah". Dengan demikian Pasolong $(2017 ; 132)$ memaparkan bahwa berkualitas mempunyai arti memuaskan kepada yang dilayani, baik internal maupun eksternal, dalam arti optimal pemenuhan ataus tuntutan/persyaratan nasabah. Kualitas (quality) menurut montgomery adalah suatu produk dikatakan berkualitas bagi seseorang jika produk tersebut dapat memenuhi kebutuhan. Kualitas harus dimulai dari nasabah dan berakhir pada nasabah. Artinya, spesifikasi kualitas layanan harus dimulai dengan mengidentifikasi kebutuhan dan keinginan nasabah yang dituangkan ke dalam harapan nasabah dan penilaian akhir diberikan oleh nasabah melaluai informasi umpan balik yang diterima perusahaan. Sehingga peningkatan kualitas pelayanan harus dilakukan dengan komunikasi yang efektif dengan nasabah. Menurut Tjiptono (2014:136) ada beberapa faktor yang dapat menyebabkan kualitas suatu jasa menjadi buruk, diantaranya sebagai berikut.

1) Produk dan konsumsi yang terjadi secara simultan

2) Salah satu dari karakteristik jasa yang paling penting adalah jassa diproduksi dan dikonsumsi pada saat bersamaan sehingga memberikan jassa dibutuhkan kehadiran partisipasi nasabah/nasabah. Akibatnya timbul masalah-masalah sehubungan dengan interaaksi antara produsen dan nasabah jasa, yang disebabkan karena tidak terampil dalam melayani nasabah, penampilan yang tidak sopan, kurang ramah, cemberut dan lain-lain.

3) Intensitas tenaga kerja yang tinggi

4) Keterlibatan tenaga kerja yang intensif dalam penyampaian jasa dapat menimbulkan masalah dalam kualitass, yaitu tingkat variabilitas yang tinggi disebabkan oleh tingkat upah dan pendidikan karyawan yang masih relative rendah, kurangnya perhatian, dan tingkat kemahiran karyawan yang tinggi.

5) Dukungan terhadap nasabah internak kurang memadahi

6) Karyawan yang berada di garis depan merupakan ujung tombak dari sistem pemberian jasa. Supaya mereka dapat memberikan jasa yang efektif maka mereka perlu mendapatkan pemberdayaan dan dukungan dari fungsi-fungsi utama manajemen sehingga nantinya mereka dapat mengendalikan dan menguasai cara melakukan pekerjaan, sadar konteks dimana pekerjaan dilaksanakan, bertanggung jawab atas output kinerja pribadi, bertanggung jawab bersama atas kinerja unit dan organisasi, keadilan dalam distribusi balas jasa berdasarkan kinerja individu dan kinerja kolektif.

Jadi kualitas adalah suatu kondisi dinamis yang memiliki keseluruhan ciri serta sifat suatu produk pelayanan yang berpengaruh pada kemampuan untuk 


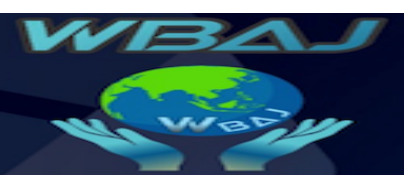

Volume 1 Issue 1, Juni 2019

http://ejournal.unsub.ac.id/index.php/bisnis

memuaskan kebutuhan yang dinyatakan atau tersirat untuk memenuhi suatu harapan akan suatu produk barang atau jasa

\section{Pengertian Pelayanan}

Secara umum pelayanan adalah setiap tindakan atau kegiatan yang dapat ditawarkan oleh suatu pihak kepada pihak lain yang pada dasarnya tidak berwujud dan tidak mengakibatkan kepemilikan apapun. Adapun mengenai pelayanan yang dikemukakan Kasmir dalam Pasolong (2017:133), “Pelayanan yang baik adalah kemampuan seseorang dalam memberikan pelayanan yang dapat memberikan kepuasan kepada nasabah dengan standar yang ditentukan. Menurut Feignbaum, kualitas adalah kepuasan nasabah sepenuhnya. Suatu produk atau jasa dikatan berkualitas apabila dapat memberikan kepuasan sepenuhnya kepada nasabah sesuai dengan apa yang diharapkan nasabah terhadap suatu produk. kualitas layanan sebagai tingkat kesempurnaan yang diharapkan dan pengendalian atas kesempurnaan tersebut untuk memenuhi keinginnan nasabah." Untuk membuat pengukuran kualitas lebih berarti dan sesuai, "tanyakan" kepada nasabah apa yang mereka inginkan, yang bisa memuaskan mereka. Pendapat tersebut dapat diartikan bahwa kedua sudut pandang tentang pelayanan itu penting, karena bagaimanapun pelayanan internal adalah langkah awal dilakukannya suatu pelayanan. Akan tetapi pelayanan tersebut harus sesuai dengan keinginan nasabah atau nasabah yang dilayani. Artinya, bagaimana pun upaya untuk memperbaiki kinerja internal harus mengarah pada apa yang diinginkan nasabah. Kalau tidak demikian, bagaimana pun perfoma suatu organisasi tetapi jika tidak sesuai dengan yang diharapkan oleh nasabah atau tidak memuaskan, citra kinerja organisasi tersebut akan dinilai tetap tidak bagus. Menurut Ratminto dan Atik (2008:24) standar ini merupakan ukuran yang dibakukan dalam penyelenggaraaan pelayanan publik yang wajib ditaati oleh pemberi dan atau penerima pelayanan, meliputi:

1) Prosedur pelayanan. Prosedur pelayanan yang dibakukan bagi pemberi dan penerima pelayanan termasuk pengaduan

2) Waktu pelayanan. Waktu penyelesaian yang ditetapkan sejak saat pengajuan permohonan sampai dengan penyelesaian pelayanan termasuk pengaduan

3) Biaya pelayanan. Biaya/tarif pelayanan termasuk rinciannya yang ditetapkan dalam proses pemberian pelayanan.

4) Produk pelayanan. Hasil pelayanan yang akan diterima sesuai dengan ketentuan yang ditetapkan.

5) Sarana dan prasarana. Penyediaan sarana dan prasarana pelayanan yang telah memadai oleh penyelenggara pelayanan publik.

6) Kompetensi petugas pemberi pelayanan. Kompetensi petugas pemberi pelayanan harus ditetapkan dengan tepat berdasarkan pengetahuan, keahlian, keterampilan, sikap dan perilaku yang dibutuhkan. 


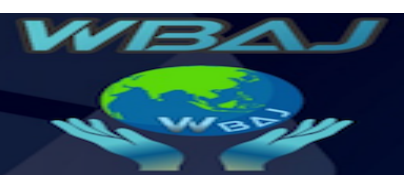

Volume 1 Issue 1, Juni 2019

http://ejournal.unsub.ac.id/index.php/bisnis

\section{Pengertian Kualitas Pelayanan}

Dari pengertian kualitas dan pelayanan, dapat di deskripsikan bahwa kualitas pelayanan adalah segala bentuk aktivitas yang dilakukan oleh perusahaan guna memenuhi harapan nasabah. Pelayanan dalam hal ini diartikan sebagai jasa atau service yang disampaikan oleh pemilik jasa yang berupa kemudahan, kecepatan, hubungan, kemampuan dan keramahtamahan yang ditujukan melalui sikap dan sifat dalam memberikan pelayanan untuk kepuasan nasabah. Menurut para ahli seperti Abidin (2010:71) mengatakan bahwa pelayanan publik yang berkualtas bukan hanya mengacu pada pelayanan itu semata, juga menekankan pada proses penyelenggaraan atau pendistribusian pelayanan itu sendiri hingga ke tangan masyarakat sebagai konsumer. Aspek-aspek kecepatan, ketepatan, kemudahan dan keadilan menjadi alat untuk mengukur pelayanan publik yang berkualitas. Hal ini berarti pemerintah melalui aparat dalam memberikan pelayanan publik kepada masyarakat harus memperhatikan aspek kecepatan, ketepatan, kemudahan dan keadilan. Adapun menurut Carism dan Schwartz dalam Denhardt (2003:61) faktor untuk mengukur kualitas pelayanan, yaitu :

1) Conveniennce (kemudahan), yaitu ukuran tingkat dimana pelayanan yang diberikan oleh pemerintah mudah didapatkan oleh masyarakat.

2) Security (keamanan), yaitu ukuran tingkat dimana pelayanan yang telah disediakan oleh pemerintah membuat masyarakat merasa aman.

3) Reliability (keandalan), yaitu ukuran tingkat dimana pelayanan pemerintah disediakan secara benar dan tepat.

4) Personal Attention (perhatian kepada orang), yaitu ukkuran tingkat dimana aparat pelayanan menyediakan informasi kepada masyarakat dan bekerja dengan masyarakat untuk memenuhi kebutuhan-kebutuhan.

5) Problem Solving Approach (pendekatan pemecahan masalah), yaitu ukuran tingkat dimana aparatur pelayanan senantiasa bersedia memberikan pemecahan masalah terhadap kasus-kasus yang dihadapi oleh masyarakat berkaitan dengan layanan yang diminta.

6) Faireness (keadilan), yaitu ukuran tingkat dimana masyarakat percaya bahwa pelayanan pemerintahan disediakan sama untuk semua orang.

7) Facial Responsibility (tanggung jawab keuangan), yaitu ukuran tingkat dimana masyarakat percaya bahwa pemerintah menyediakan pelayanan sebagaimana mestinya yang menggunakan uang rakyat secara bertanggungjawab.

8) Citizen Infuence (pengaruh masyarakat), yaitu ukuran tinggi dimana masyarakat percaya bahwa mereka dapat mempengaruhi kualitas pelayanan yang diterima dari pemerintah.

Akan tetapi Menurut Parasuraman, Zeithaml, dan Berry (dalam Tjiptono, 1998:69) yang melalukan penelitian khusus terhadap beberapa jenis pelayanan, mengidentifikasi sepuluh faktor utama yang menentukan kualitas pelayanan, yakni :

1) Realibility, yang mencakup konsistensi kerja (performance) dan kemampuan untuk dipercaya (dependability). 


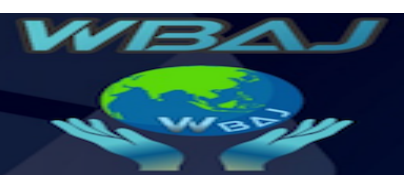

Volume 1 Issue 1, Juni 2019

http://ejournal.unsub.ac.id/index.php/bisnis

2) Responsiveness, yaitu kemauan atau kesiapan para pegawai untuk memberikan pelayanan yang dibutuhkan nasabah.

3) Competence, artinya setiap pegawai perusahaan memiliki pengetahuan dan ketrampilan yang dibutuhkan untuk dapat memberikan pelayanan tertentu.

4) Access, yaitu kemudahan untuk dihubungi atau ditemui, yang berarti lokasi fasilitas pelayanan mudah dijangkau, waktu menunggu tidak terlalu lama, saluran komunikasi mudah dihubungi.

5) Courtesy, yaitu sikap sopan santun, respek, perhatian, dan keramahan dari para kontak personal perusahaan

6) Communication, yaitu memberikan informasi yang dapat dipahami nasabah serta selalu mendengarkan saran dan keluhan nasabah.

7) Credibility, yaitu jujur dan dapat dipercaya. Disini menyangkut nama dan reputasi perusahaa, karakteristik pribadi, kontak personal, dan interaksi dengan nasabah.

8) Security, yaitu aman (secara fisik, finansial dan kerahasiaan) dari bahaya, resiko atau keragu-raguan.

9) Understanding/knowing the customer, yaitu upaya untuk memahami kebutuhan nasabah.

10) Tangible, yaitu segala bukti fisik seperti pegawai, fasilitas, peralatan, tampilan fisik dari pelayanan misalnya kartu kredit plastik.

Adapun dalam perkembangan menurut Parasuraman dalam Zeithaml dan Bitner (1996: 118) bahwa kesepuluh dimensi kualitas pelayanan di atas dirangkumkan menjadi lima dimensi pokok yang terdiri dari reliability, responsiveness, assurance (yang mencakup competence, courtesy, credibility, dan security), empathy (yang mencakup access, communication dan understanding the customer), serta tangible. Penjelasan kelima dimensi untuk menilai kualitas pelayanan sama seperti yang di deskripsikan Tjiptono (2015;282) yang disebut model SERVQUAL, penjelasannya sebagai berikut :

1) Wujud (Tangibles),

2) Tangible merupakan kemampuan suatu perusahaan dalam menunjukan kesistensinya kepada pihak eksternal. Penampilan dan kemampuan sarana dan prasarana fisik perusahaan yang dapat diandalkan dan keadaan lingkungan sekitarnya merupakan bukti nyata dari pelayanan yang diberikan oleh pemberi jasa. Hal ini berkaitan dengan fasilitas fisik, penampilan karyawan, peralatan dan tenologi yang diberikan dalam memberikan layanan. Fasilitas fisik seperti gedung, ruang tempat pelayanan, kebersihan, ruang tunggu, $\mathrm{AC}$, tempat parkir merupakan salah satu segi dalam kualitas jasa karena akan memberikan sumbangan bagi nasabah yang memerlukan layanan dari perusahaan. Penampilan yang baik dari karyawan akan memberikan rasa dihargai bagi nasabah yang dilayani, sedangkan dalam peralatan dan teknologi yang digunakan dalam memberikan pelayanan akan berkontribusi pada kecepatan dan ketepatan layanan.

3) Kehandalan (Reliability) 


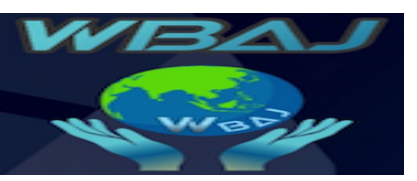

Volume 1 Issue 1, Juni 2019

http://ejournal.unsub.ac.id/index.php/bisnis

4) Reliability yaitu kemampuan untuk memberikan layanan sesuai dengan yang dijanjikan secara akurat dan terpercaya. Kinerja harus sesuai dengan harapan nasabah yang berarti harus tepat waktu, pelayanan yang sama untuk semua nasabah tanpa kesalahan, sikap yang simpatik, dan dengan akurasi tinggi.

5) Ketanggapan (Responsiveness)

6) Responsiveness yaitu suatu kebijakan untuk membantu memberikan pelayanan yang cepat dan tepat kepada nasabah, dengan penyampaian informasi yang jelas. Membiarkan nasabah menunggu menyebabkan persepsi yang negatif dalam kualitas pelayanan.

7) Jaminan (Assurance)

8) Assurance yaitu kemampuan, kesopanan, dan kemampuan karyawan perusahaan. Hal ini meliputi beberapa komponen antara lain komunikasi (communication), kredibilitas (credibility), keamanan (security), kompetensi (competence), dan sopan santun (courtesy). Berkaitan dengan kemampuan para karyawan dalam menanamkan kepercayaan kepada nasabah, adanya perasaan aman bagi nasabah dalam melakukan transaksi, pengertian dan sopan santun karyawaan dalam memberikan pelayanan kepada nasabah. Pengetahuan, kesopanan, dan kemampuan karyawan akan menimbulkan kepercayaan dan keyakinan terhadap perusahaan.

9) Empati (Empathy)

10) Empathy yaitu memberikan perhatian yang tulus dan bersifat individual atau pribadi yang diberikan kepada para nasabah dengan berupaya memahami keinginan nasabah. Hal ini berhubungan dengan perhatian dan kepedulian karyawan terhadap masalah yang dihadapinya. Semua nasabah berhak memperoleh kemudahan pelayanan yang sama tanpa didasari apakah mempunyai hubungan khusus kepada karyawan atau tidak.

\section{Kepuasan Nasabah}

Kepuasan nasabah adalah penilaian nasabah terhadap produk atau pelayanan yang telah memberikan tingkat kenikmatan seperti yang diharapkan. Setiap kegiatan usaha dalam hal penjualan berkaitan dengan kepuasan nasabah. Dengan adanya kepuasan nasabah, maka kelangsungan usaha pun akan terjaga. Adapun menurut para ahli, seperti Kotler (2015:211) mendefinisikan kepuasan sebagai tingkatan perasaan seseorang setelah membandingkan kinerja (hasil) yang ia rasakan dibandingkan dengan harapannya. Tingkat kepuasan adalah fungsi dari perbedaan antara kinerja yang dirasakan dengan harapan. Nasabah dapat mengalami salah satu dari tiga tingkat yang umum. Apabila kinerja di bawah harapan, maka nasabah akan kecewa. Apabila kinerja sesuai harapan, maka nasabah akan merasa puas. Apabila kinerja melebihi harapan, maka nasabah akan sangat puas. Nasabah menurut Tjiptono $(2014 ; 368)$ ingin membeli suatu produk dengan harapan akan memberikan manfaat pada saat digunakan berdasarkan kinerja atau manfaat produk yang telah dibeli atau dipakainya diperbandingkan dengan harapan dan hasil penilaiannya dibagi atas tiga kategori, 


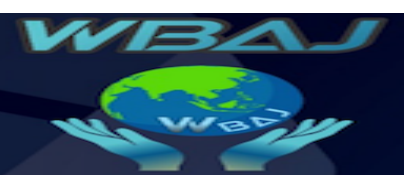

Volume 1 Issue 1, Juni 2019

http://ejournal.unsub.ac.id/index.php/bisnis

yaitu: 1 ) Dikonfirmasi positif (Dimana kinerja melebihi harapan yang menghasilkan respon kepuasan tinggi dan akan kembali untuk membeli lagi); 2) Diskonfirmasi sederhana (Dimana kinerja sesuai dengan harapan yang menyiratkan suatu respon netral dan mempengaruhi keinginan untuk membeli lagi); dan 3) Diskonfirmasi negatif

Dimana kinerja lebih rendah dari harapan sehingga tidak ada keinginan kembali untuk membeli. Jadi tingkat kepuasan merupakan fungsi dari perbedaan antara kinerja yang dirasakan dengan harapan. Apabila kinerja tidak memenuhi harapan nasabah maka nasabah akan kecewa, apabila kinerja melebihi harapan maka nasabah akan puas dan apabila kinerja melebihi harapan maka nasabah akan sangat puas. Harapan nasabah merupakan keyakinan nasabah sebelum mencoba atau membeli suatu produk yang akan dijadikan standar acuan untuk menilai kinerja produk tersebut. harapan nasabah dibentuk oleh pengalaman masa lalu, informasi dari kenalan dan iklan. Adapun menurut Kotler $(2015 ; 61)$ menyatakan bahwa "kepuasan nasabah adalah tanggapan nasabah atas terpenuhnya kebutuhan sedangkan Kotler mendefinisikan kepuasan sebagai perasaan kecewa seseorang yang dialami setelah membandingkan antara persepsi kinerja atau hasil suatu produk dengan harapan-harapanya." Di jelaskan juga oleh Kotler (2015:10) menegaskan bahwa : "kepuasan nasabah yaitu tingkatan di mana anggapan kinerja (perceived performence) produk akan sesuai dengan harapan seorang nasabah. Bila kinerja produk jauh lebih rendah dibandingkan harapan seorang nasabah, pembelinya tidak puas. Sebaliknya, apabila kinerja sesuai dengan harapan atau melebihi harapan, pembelinya merasa puas atau sangat puas." Menurut Ratminto (2014:222) indeks Kepuasan nasabah adalah untuk mengetahui tingkat kinerja unit pelayanan secara berkala sebagai bahan untuk menetapkan kebijakan dalam rangka peningkatan kualitas." Dari beberapa pendapat di atas, definisi kepuasan nasabah tampak bahwa kepuasan nasabah adalah respon dari perilaku yang ditunjukan oleh nasabah atau penerima jasa pelayanan dengan membandingkan kinerja yang dirasakan dengan harapan. Apabila kinerja yang dirasakan dibawah harapan, maka nasabah akan kecewa, kurang puas atau tidak puas sama sekali. Namun sebaliknya, apabila kinerja yang dirasakan sesuai dengan harapan atau melebihi harapan, maka nasabah akan merasa puas atau sangat puas.

\section{Dimensi Kepuasan Nasabah}

Saat ini nasabah menghadapi banyak pilihan dalam memilih suatu produk/jasa yang dapat mereka beli. Nasabah akan membeli dari perusahaan yang mereka anggap menawarkan nilai bagi nasabah yang tertinggi, yaitu selisih antara total manfaat yang diperoleh nasabah dari produk/jasa dan total pengorbanan yang diperkirakan nasabah akan terjadi dalam mengevaluasi, memperoleh dan menggunakan produk/jasa. Ada dua alternatif apabila perusahaan kalah bersaing dalam memberikan nilai yaitu; alternatif pertama, meningkatkan nilai total nasabah dengan cara meningkatkan produk, pelayanan karyawan dan citra perusahaan. Alternatif kedua, pengurangan biaya/pengorbanan nasabah dengan cara menurunkan harganya, penyederhanaan proses pemesanan dan penyerahan serta mengurangi resiko pembeli dengan 


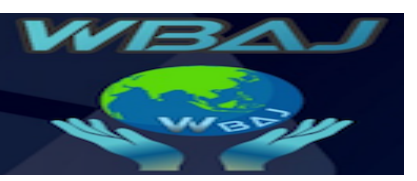

Volume 1 Issue 1, Juni 2019

http://ejournal.unsub.ac.id/index.php/bisnis

menawarkan garansi. Sedangkan untuk kepuasan nasabah terdapat dua jenis, yang pertama adalah kepuasan fungsional dan yang kedua adalah kepuasan psikologikal. Kepuasan fungsional merupakan kepuassan yang diperoleh dari fungsi atau pemakaian suatu produk/jasa. Kepuasan psikologikal merupakan kepuasan yang diperoleh dari atribut yang tidak berwujud. Dalam hal implementasi pengukuran kepuasan nasabah, terdapat tiga aspek penting yang saling berkaitan: (1) apa yang diukur (objek pengukuran); (2) metode pengukuran; dan (3) skala pengukuran. Menginngat kepuasan nasabah merupakan ukuran relatif, maka pengukuranya tidak boleh hanya bersifat 'one time, single-shot studies'. Justru sebaiknya pengukuran kepuasan nasabah harus dilakukan secara reguler setiap nasabah. Selain itu, perusahaan juga dapat melakukan patok duga (banchmarking) dengan kinerja masa lalu dan kinerja pesaing, baik dalam industri sejenis maupun berbeda. Menurut Irawan (2004 : 37), faktor - faktor yang pendorong kepuasan nasabah adalah sebagai berikut:

1) Kualitas produk, nasabah puas kalau setelah membeli dan menggunakan produk tersebut ternyata kualitas produknya baik.

2) Harga, untuk nasabah yang sensitive, biasanya harga murah adalah sumber kepuasan yang penting karena nasabah akan mendapatkan value for money yang tinggi.

3) Service quality, kepuasan terhadap kualitas pelayanan biasanya sulit ditiru. Kualitas pelayanan merupakan driver yang mempunyai banyak dimensi, salah satunya yang popular adalah SERVQUAL.

4) Emotional Factor, nasabah akan merasa puas (bangga) karena adanya emosional value yang diberikan oleh brand dari produk tersebut.

5) Biaya dan kemudahan, nasabah akan semakin puas apabila relative mudah, nyaman dan efisien dalam mendapatkan produk atau pelayanan.

Faktor-faktor yang mempengaruhi persepsi dan harapan nasabah menurut Gaspersz dalam Nasution (2005:50) adalah sebagai berikut:

1. Kebutuhan dan keinginan yang berkaitan dengan hal-hal yang dirasakan nasabah ketika ia sedang mencoba melakukan transaksi dengan produsen/pemasok produk (perusahaan). Jika pada saat itu kebutuhan dan keinginannya besar, harapan atau ekspektasi nasabah akan tinggi, demikian pula sebaliknya.

2) Pengalaman masa lalu ketika mengkonsumsi produk dari perusahaan maupun pesaing-pesaingnya.

3) Pengalaman dari teman-teman, dimana mereka akan menceritakan kualitas produk yang akan dibeli oleh nasabah itu. Hal ini jelas mempengaruhi persepsi nasabah terutama pada produk-produk yang dirasakan berisiko tinggi.

4) Komunikasi melalui iklan dan pemasaran juga mempengaruhi persepsi nasabah. Orang-orang di bagian penjualan dan periklanan seyogianya tidak membuat kampanye yang berlebihan melewati tingkat ekspetasi nasabah.

5) Menurut Garvin dalam Tjiptono (1996:126) ada beberapa dimensi yang dipergunakan untuk mengukur kepuasan nasabah, yaitu : 


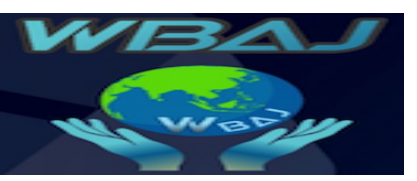

Volume 1 Issue 1, Juni 2019

http://ejournal.unsub.ac.id/index.php/bisnis

6) Kinerja karakteristik operasi pokok dari produk inti (core product) yang dibeli.

7) Ciri-ciri tambahan, yaitu karakteristik sekunder atatu pelengkap.

8) Kehandalan, yaitu sangat kecil risiko terjadi kerusakan (tidak dapat dipergunakannya suatu produk)

9) Kesesuaian dengan spesifikasi dan standar yang telah ditatapkan.

10) Daya tahan, berkaitan dengan berapa lama suatu produk dapat terus digunakan.

11) Servicebility, melputi kecepatan, kompetensi, kenyamanan, kemudahan untuk direparasi, serta penanganan keluhan yang memuaskan.

12) Estetika, yaitu daya tarik produk terhadap panca indera.

13) Perceived quality, yaitu citra dan reputasi produk serta tanggung jawab perusahaan terhadapnya.

\section{Metode Penelitian}

Penelitian ini menggunakan jenis penelitian kuantitatif yaitu penelitian yang dituntut menggunakan angka, mulai pengumpulan data, penafsiran terhadap data tersebut, serta penampilan dan hasilnya. Demikian juga pemahaman akan kesimpulan penelitian disertai dengan tabel grafik, bagan atau tampilan lainnya. Pendekatan kuantitatif menggambarkan atau menjelaskan suatu masalah yang hasilnya dapat digeneralisasikan. Dengan demikian tidak terlalu mementingkan kedalaman data atau analisis. Peneliti lebih mementingkan aspek keluasaan data sehingga data atau hasil penelitian dianggap merupakan representasi dari seluruh populasi. Adapun pengertian tentang metode kuantitatif, Menurut Sugiyono (2014:13) "Metode kuantitatif dapat diartikan sebagai metode penelitian yang dilandaskan pada filsafat positivisme (filsafat positivisme memandang realitas atau gejala atau fenomena itu dapat diklasifikasikan, relative tetap, konkrit, teramati, terukur, dan hubungan gejala bersifat sebab akibat), digunakan untuk meneliti pada populasi atau sampel tertentu, teknik pengambilan sampel tertentu, teknik pengambilan sampel pada umumnya dilakukan secara random, tetapi peneliti menggunakan metode survei, pengumpulan data menggunakan instrument penelitian, analisis data bersifat kuantitatif atau statistik dengan tujuan untuk menguji hipotesis yang telah ditetapkan.

\section{Hasil dan Pembahasan}

\section{Sejarah Singkat PT. Bank Mandiri Republik Indonesia}

PT Bank Mandiri Tbk, yang selanjutnya disebut Bank Mandiri didirikan di Negara Indonesia pada tanggal 2 Oktober 1998 berdasarkan peraturan pemerintah No. 75 Tahun 1998 Tanggal 1 Oktober 1998. Akta pendirian telah disahkan oleh menteri kehakiman berdasarkan Surat Keputusan No. C2- 561NHT. 01. Tahun 98 tanggal 2 Oktober 1998, serta diumumkan pada tambahan No. 6859 dalam berita Negara Republik Indonesia No. 97 tanggal 4 Desemeber 1998. Pada bulan Juli 1999 Bank Mandiri didirikan melalui pengalihan hampir seluruh Saham Pemerintah Republik Indonesia yaitu PT Bank Bumi Daya (Persero), PT Bank Dagang Negara (Persero), PT Bank Expor Indonesia (Persero), dan PT Pembangungan Indonesia dan Setoran Tunai 


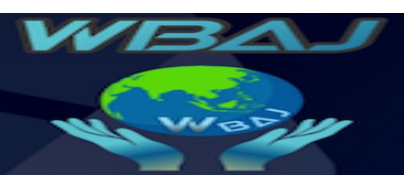

Volume 1 Issue 1, Juni 2019

http://ejournal.unsub.ac.id/index.php/bisnis

Pemerintah. Bank Dagang Negara (BDN) merupakan salah satu bank tertua di Indonesia. Sebelumnya Bank Dagang Negara (BDN) dikenal sebagai Nederlanchsch Indische Escompto Maaatschappij yang didirikan di Batavia (Jakarta) pada tahun 1957. Pada tahun 1949 namanya berubah menjadi EscomptobankNV. Selanjutnya pada tahun 1960 Escomtobank di nasionalisasi dan berubah menjadi Bank Dagang Negara (BDN), sebuah bank pemerintah yang membiayai sektor industi dan pertambangan.Bank Bumi Daya (BDD) didirikan melalui suatu proses panjang yang bermula dari sebuah perusahaan Belanda, De Nationale Handlesbank NV, menjadi Bank Umum Negara pada tahun 1959. Pada tahun 1964 Chartered Bank(sebelumnya adalah bank milik Inggris) juga dinasionalisasi, dan Bank Umum Negara diberi hak untuk melanjutkan operasi teresebut. Pada tahun 1965, Bank Umum Negara digabung ke dalam Bank Negara Indonesia Unit IV beralih menjadi Bank Bumi Daya. Bank Ekspor Impor Indonesia (Bank Exim) berawal dari perusahaan dagang Belanda NV, Nederlanche Handels Maaatschappij yang didirikan pada tahun 1870. Pemerintah Indonesia menasionalkan perusahaan ini pada tahun 1960, dan selanjutnya pada tahun 1965. Bank Umum Negara Indonesia Unit II dipecah menjadi dua unit, salah satunya adalah Bank Negara Indonesia Unit II Divisi Expor-Impor, yang akhirnya menjadi Bank Exim, Bank Pemerintah yang membiayai kegiatan ekspor dan impor.

\section{Pengaruh Kualitas Pelayanan Terhadap Kepuasan Nasabah Pt.Bank Mandiri Republik Indonesia Unit Tanjung Siang}

1) Pengujian Instrumen Penelitian

Variabel penelitian ini terdiri dari dua variabel, yaitu variabel Kualitas pelayanan sebagai variabel bebas yang diberi symbol X, dan variabel Kepuasan nasabah sebagai variabel tidak bebas yang diberi symbol Y. pada penelitian ini yang dijadikan sebagai unit analisis adalah para Nasabah Kantor PT. Bank Mandiri Republik Indonesia Unit Tanjungsiang Cabang Subang, dengan keseluruhan jumlah karyawan sebanyak 26 orang, dan juga sampel yang diambil sebanyak 96 orang sebagai responden. Selanjutnya kepada responden tersebut diajukan pernyataan-pernyataan dalam bentuk angket yang merupakan penjabaran dari indikator-indikator variabel Kualitas pelayanan dan variable Kepuasan nasabah. Indikator-indikator dalan setiap variabel penelitian dituangkan ke dalam pernyataan, dimana setiap pernyataan angket memiliki lima alternatif jawaban yang dapat dipilih oleh responden. Alternatif tersebut diberi skor dari 5 sampai 1 sesuai dengan skala likert sehingga diperoleh data ordinal. Data ordinal tersebut kemudian ditransformasi ke dalam interval.

2) Uji Validitas

Hasil uji validitas untuk kuesioner Kepuasan nasabah dengan $\mathrm{dk}$ atau $\mathrm{df}=96-2$ $=94$ pada tingkat signifikansi $(\alpha)$ sebesar $5 \%$ atau 0,05 diperoleh nilai $\mathrm{r}$ tabel $=$ 0,2006 bahwa item-item kuesioner memiliki nilai $r$ hitung yang positif dan $r$ hitung $>$ $\mathrm{r}$ tabel, sebagaimana kriteria yang telah ditetapkan diatas. Hal ini menunjukkan bahwa item-item ini sudah valid. Pertama dilakukan pengujian validitas untuk 


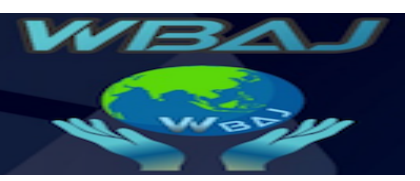

Volume 1 Issue 1, Juni 2019

http://ejournal.unsub.ac.id/index.php/bisnis

kuesioner Kualitas pelayanan $\left(\mathrm{X}_{1}\right)$ yang terdiri dari 18 butir pernyataan. Hasil pengujian menunjukkan bahwa pernyataan untuk kuesioner variabel $X_{1}$ sudah valid, sebab memiliki nilai $r$ hitung yang positif dan $r_{h i t u n g}>r_{\text {tabel }}$. Artinya item-item tersebut dapat mengukur apa yang ingin kita ukur. Untuk lebih jelasnya dapat dilihat pada tabel dibawah ini :

Tabel 1

Tingkat Validitas Variabel $X_{1}$

\begin{tabular}{|c|c|c|c|}
\hline Pernyataan & $\mathbf{r}_{\text {hitung }}$ & $\mathbf{r}_{\text {tabel }}$ & Keterangan \\
\hline X1.1. & 0,90902 & 0,2006 & Valid \\
\hline X1.2. & 0,91255 & 0,2006 & Valid \\
\hline X1.3. & 0,85332 & 0,2006 & Valid \\
\hline X1.4. & 0,87187 & 0,2006 & Valid \\
\hline X1.5. & 0,91282 & 0,2006 & Valid \\
\hline X1.6. & 0,89762 & 0,2006 & Valid \\
\hline X1.7. & 0,85281 & 0,2006 & Valid \\
\hline X1.8. & 0,90794 & 0,2006 & Valid \\
\hline X1.9. & 0,85336 & 0,2006 & Valid \\
\hline X1.10. & 0,89858 & 0,2006 & Valid \\
\hline X1.11. & 0,90862 & 0,2006 & Valid \\
\hline X1.12. & 0,82977 & 0,2006 & Valid \\
\hline X1.13. & 0,89762 & 0,2006 & Valid \\
\hline X1.14. & 0,85336 & 0,2006 & Valid \\
\hline X1.15. & 0,87187 & 0,2006 & Valid \\
\hline X1.16. & 0,91255 & 0,2006 & Valid \\
\hline
\end{tabular}

Sumber : Hail Penelitian

Ketiga, dilakukan pengujian Validitas untuk kuesioner variabel Kepuasan nasabah (Y) yang terdiri dari 4 butir pernyataan menunjukan bahwa kesemua item/pernyataan variabel Kepuasan nasabah sudah valid, sebab memiliki nilai $r_{\text {hitung }}$ yang positif dan $r_{\text {hitung }}>r_{\text {tabel }}$. Artinya, item-item tersebut dapat mengukur apa yang ingin kita ukur. Untuk lebih jelasnya dapat dilihat pada tabel dibawah ini: 


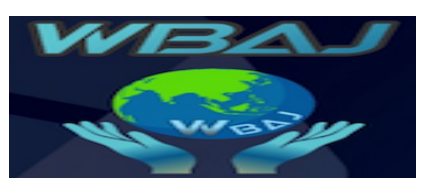

Volume 1 Issue 1, Juni 2019

http://ejournal.unsub.ac.id/index.php/bisnis

Tabel 2

Tingkat Validitas Variabel $Y_{1}$

\begin{tabular}{|c|c|c|c|}
\hline Pernyataan & rhitung & rtabel & Keterangan \\
\hline Y.1 & 0,91255 & 0,2006 & Valid \\
\hline Y.2 & 0,88954 & 0,2006 & Valid \\
\hline Y.3 & 0,90774 & 0,2006 & Valid \\
\hline Y.4 & 0,91219 & 0,2006 & Valid \\
\hline Y.5 & 0,85281 & 0,2006 & Valid \\
\hline Y.6 & 0,90794 & 0,2006 & Valid \\
\hline Y.7 & 0,90774 & 0,2006 & Valid \\
\hline Y.8 & 0,91255 & 0,2006 & Valid \\
\hline Y.9 & 0,85336 & 0,2006 & Valid \\
\hline
\end{tabular}

Sumber : Hasil Penelitian

3) Uji Reliabilitas

Uji reliabilitas dimaksudkan untuk menguji konsistensi kuesioner dalam mengukur suatu kontrak yang sama atau stabilitas kuesioner jika digunakan dari waktu ke waktu. Reliabilitas instrumen penelitian dalam penelitian ini diuji dengan menggunakan koefisien cronbach's alpha. Jika nilai koefisien alpha lebih besar dari 0,6 maka disimpulkan bahwa instrumen penelitian tersebut handal atau reliabel (Nunnally dalam Ghozali, 2011). Adapun hasil dari pengujian reliabilitas adalah sebagai berikut :

Tabel 3

Hasil Uji Reliabilitas

\begin{tabular}{|c|c|c|c|}
\hline Variabel & Ketentuan & Nilai Alpha & Keterangan \\
\hline $\mathrm{X} 1$ & 0,6 & 0.832 & Reliabel \\
\hline $\mathrm{Y}$ & 0,6 & 0.844 & Reliabel \\
\hline
\end{tabular}

Sumber : Data primer yang telah diolah

Berdasarkan tabel diatas terlihat bahwa variabel Perepsi Merek dan Kepuasan nasabah (X1) dan variabel Kepuasan nasabah (Y) memiliki status reliabel. hal ini dikarenakan nilai Cronbach Alpha variabel tersebut lebih besar dari 0,7, kondisi ini juga memberikan arti bahwa seluruh variabel tersebut dapat digunakan pada analisis selanjutnya.

Method Successive Interval (MSI) digunakan untuk menganalisis diperlukan data dengan ukuran yang paling tidak interval sampai persyaratan menggunakan alat analisis regresi berganda, oleh karena itu seluruh variabel yang berskala ordinal terlebih dahulu dinaikkan atau ditransformasikan tingkat kepengukurannya 


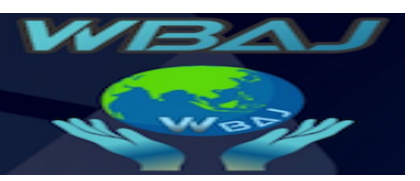

Volume 1 Issue 1, Juni 2019

http://ejournal.unsub.ac.id/index.php/bisnis

ketingkat interval melalui method successive interval (MSI). Pengolahan data (terlampir).

4) Uji Asumsi Klasik

Uji Normalitas

Uji normalitas bertujuan untuk menguji apakah dalam model regresi, variabel dependen dan variabel independen keduanya mempunyai distribusi normal atau tidak. Model regresi yang baik adalah yang mempunyai distribusi data normal atau yang mendekati normal (Ghozali, 2011:160). Pada prinsipnya normalitas dapat dideteksi dengan melihat penyebaran data (titik) pada sumbu diagonal dari grafik atau dengan melihat histogram dari residualnya. Dasar pengambilan keputusan:

(1). Jika data menyebar disekitar garis diagonal dan mengikuti arah garis diagonal atau grafik histogramnya menunjukan pola distribusi normal, maka model regresi memenuhi asumsi normalitas.

(2). Jika data menyebar jauh dari diagonal dan/atau tidak mengikuti arah garis diagonal atau grafik histogram menunjukan pola distribusi normal, maka model regresi tidak memenuhi asumsi normalitas (Ghozali, 2011:163).

\section{Dependent Variable: minat beli}

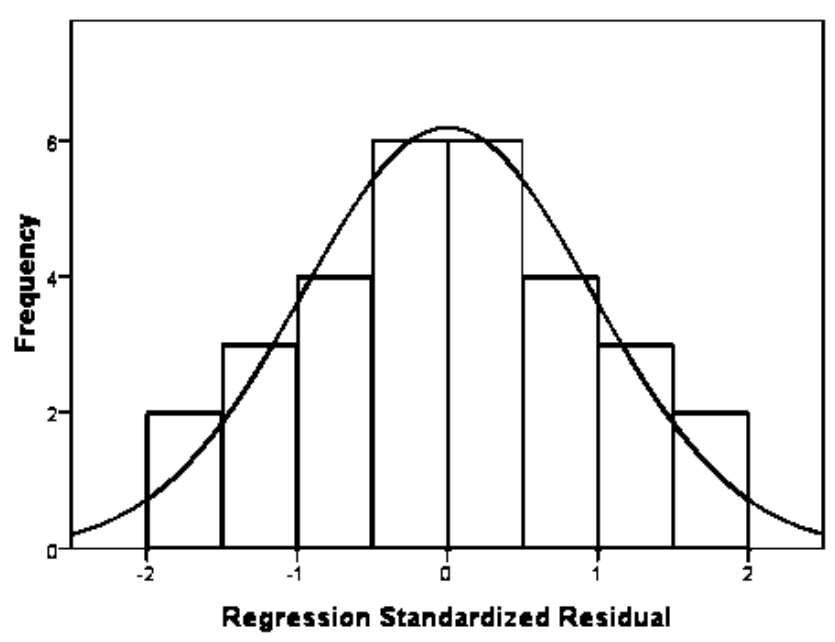




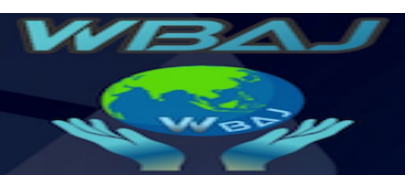

Volume 1 Issue 1, Juni 2019

http://ejournal.unsub.ac.id/index.php/bisnis

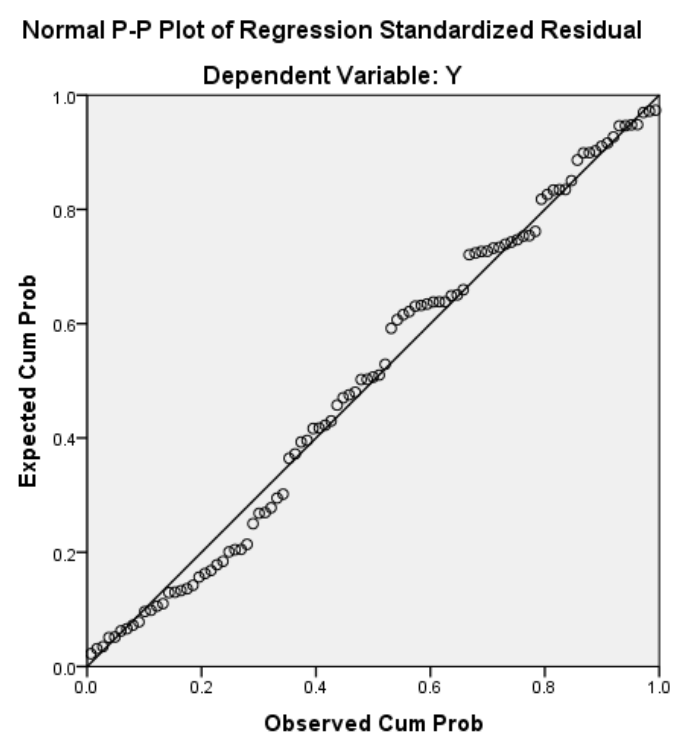

Gambar 1

Hasil Uji Normalitas dengan Analisis Grafik Histogram dan Grafi P-Plot

Dengan melihat tampilan grafik normal plot dapat disimpulkan bahwa grafik histogram memberikan pola distribusi yang normal. Sedangakan pada grafik plot terlihat titik - titik menyebar disekitar garis diagonal. Pada prinsipnya normalitas dapat dideteksi dengan melihat histogram dari residualnya. Artinya, model regresi memenuhi asumsi normalitas.

Uji Multikolonieritas

Uji Multikolineritas bertujuan untuk menguji apakah dalam suatu model regersi ditemukan adanya korelasi antar variabel bebas (independen). Model regresi yang baik seharusnya tidak terjadi koreasi diantara variabel independen (bebas). Untuk mendeteksi ada atau tidaknya Multikolineritas didalam regresi dapat dilihat dari nilai tolerance dan nilai Variance Inflasing Faktor (VIF). Kedua ukuran ini menunjukan setiap variabel bebas manakah yang dijelaskan oleh variabel bebas lainnya. Tolerance mengukur variabilitas variabel independen yang terpilih yang tidak dijelaskan oleh variabel independen lainnya. Jadi nilai tolerance yang rendah sama dengan nilai VIF tinggi (karena VIF $=1$ /Tolerance). Nilai cutoff yang umum dipakai untuk menunjukkan adanya multikolinearitas adalah nilai tolerance < 0,10 atau sama dengan nilai VIF > 10 (Ghozali, 2011:105). Pengujian multikolinearitas dilakukan dengan menggunakan nilai VIF. hasil pengujian diperoleh sebagai berikut : 


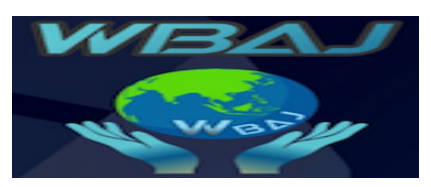

Volume 1 Issue 1, Juni 2019

http://ejournal.unsub.ac.id/index.php/bisnis

\section{Tabel 4}

\section{Hasil Pengujian Multikolinieritas}

\begin{tabular}{|c|c|c|c|c|c|c|c|c|c|c|}
\hline \multirow[b]{2}{*}{ Model } & \multicolumn{2}{|c|}{$\begin{array}{l}\text { Unstandardized } \\
\text { Coefficients }\end{array}$} & $\begin{array}{l}\text { Standardized } \\
\text { Coefficients }\end{array}$ & \multirow[b]{2}{*}{$t$} & \multirow[b]{2}{*}{ Sig. } & \multicolumn{3}{|c|}{ Correlations } & \multicolumn{2}{|c|}{$\begin{array}{r}\text { Collinearity } \\
\text { Statistics }\end{array}$} \\
\hline & B & Std. Error & Beta & & & Zero-order & Partial & Part & Tolerance & VIF \\
\hline $\begin{array}{l}\text { (Constant) } \\
\mathrm{X}\end{array}$ & $\begin{array}{r}24.687 \\
.039\end{array}$ & $\begin{array}{r}2.998 \\
.064\end{array}$ & .063 & $\begin{array}{r}8.235 \\
.604\end{array}$ & $\begin{array}{l}.000 \\
.547\end{array}$ & .063 & .063 & .063 & 1.000 & 1.000 \\
\hline
\end{tabular}

Dari hasil tersebut menunjukan bahwa saemua variabel bebas mempunyai nilai Variance Infation Factor (VIF) yang berada jauh dibawah dibawah angka 10 sehingga dapat dikatakan semua konsep pengukuran vaariabel-variabel yang digunakan tidak ada multikolinearitas. Maka model regresi yang ada layak untuk dipakai dalam memprediksi Minat Beli Konsumen.

Analisis Korelasi Rank Spearman

Analisis korelasi rank spearman digunakan untuk mengetahui bagaimana hubungan Kualitas pelayanan $\left(\mathrm{X}_{1}\right)$ terhadap Kepuasan nasabah $(\mathrm{Y})$. Hasil pengolahan data menggunakan SPSS For Window Version 17.0 dapat dilihat pada tabel berikut :

Tabel 5

Korelasi Rank Spearman

Correlations

\begin{tabular}{|lll|r|r|}
\hline & & \multicolumn{1}{c|}{ X } & \multicolumn{1}{c|}{$\mathrm{Y}$} \\
\hline $\begin{array}{c}\text { Spearman's } \\
\text { rho }\end{array}$ & $\mathrm{X}$ & Correlation & 1.000 & .061 \\
& & $\quad$ Coefficient & & .554 \\
& & Sig. (2-tailed) &. & 95 \\
\cline { 2 - 5 } & $\mathrm{N}$ & .061 & 1.000 \\
& $\mathrm{Y}$ & Correlation & \\
& $\quad$ Coefficient & .554 &. \\
& Sig. (2-tailed) & 95 & 95 \\
& $\mathrm{~N}$ & & \\
\end{tabular}

Berdasarkan table diatas bahwa hubungan kualitas pelayanan dan kepuasan nasabah adalah sebesar 0.061 bila dikaitkan dengan koefisian korelasi Rank Spearman (Riduwan, 2003;228), maka hubungan kualitas pelayanan dan kepuasan nasabah adalah sangat rendah sekali.

Uji Regresi (Parameter ) Secara Parsial (Uji T)

Uji t ini dimaksudkan untuk mengetahui pengaruh secara parsial (individu) variabel-variabel independen yaitu Kualitas pelayanan terhadap variabel 


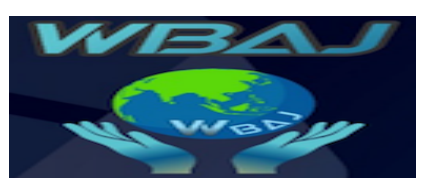

Volume 1 Issue 1, Juni 2019

http://ejournal.unsub.ac.id/index.php/bisnis

dependen yaitu Kepuasan nasabah. Adapun hipotesis uji regresi adalah sebagai berikut:

Ho = Tidak terdapat pengaruh yang signifikan antara Kualitas pelayanan terhadap Kepuasan nasabah.

$\mathrm{Ha}=$ Terdapat pengaruh yang signifikan antara Kualitas pelayanan dan terhadap Kepuasan nasabah.

Dari hasil regresi telah diperoleh suatu bentuk persamaan sebagai berikut:

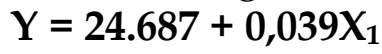

Jika thitung $>t_{\text {tabel }}$ maka Ho ditolak atau Ha diterima. Dari hasil perhitungan melalui SPSS versi 17.00 diperoleh nilai thitung sebagai berikut:

Tabel 6

Pengujian Hipotesis

Coefficients ${ }^{a}$

\begin{tabular}{|c|c|c|c|c|c|}
\hline \multirow[b]{2}{*}{ Model } & \multicolumn{2}{|c|}{$\begin{array}{c}\text { Unstandardized } \\
\text { Coefficients }\end{array}$} & \multirow{2}{*}{\begin{tabular}{|c}
$\begin{array}{c}\text { Standardize } \\
\mathrm{d} \\
\text { Coefficie } \\
\text { nts }\end{array}$ \\
Beta \\
\end{tabular}} & \multirow[b]{2}{*}{$\mathrm{t}$} & \multirow[b]{2}{*}{ Sig. } \\
\hline & $\mathrm{B}$ & Std. Error & & & \\
\hline $1 \quad$ (Constant & 24.687 & 2.998 & & 8.235 & .000 \\
\hline $\bar{X}$ & .039 & .064 & .063 & .604 & .547 \\
\hline
\end{tabular}

Dari hasil perhitungan didapat nilai thitung sebesar 0.604 sedangkan $t_{\text {tabel }}$ diketahui dengan df (derajat kebebasan) $=\mathrm{n}-2$ yaitu $96-2=94$, sehingga diperoleh nilai sebesar 1,667, berdasarkan kriteria dapat diketahui bahwa $t_{\text {hitung }}<t_{\text {tabel }}$ yaitu $0.604<$ 1.667 maka Ho diterima, artinya Kualitas pelayanan tidak berpengaruh signifikan secara parsial (individu) terhadap Kepuasan nasabah.

Analisis Koefisien Determinasi

Setelah koefesien regresi sudah diketahui dan sudah diuji signifikan tidaknya, maka selanjutnya harus dihitung koefesien determinasi untuk mengetahui besarnya pengaruh dari Kualitas pelayanan $\left(\mathrm{X}_{1}\right)$ terhadap Kepuasan nasabah $(\mathrm{Y})$. Untuk melihat hasil perhitungan koefesien determinasi dapat dilihat pada tabel SPSS versi 17.00 berikut ini: 


\section{Tabel 7}

\section{Koefisien Determinasi}

Model Summaryb

\begin{tabular}{|c|c|c|c|c|c|c|}
\hline \multirow[b]{2}{*}{ Model } & \multirow[b]{2}{*}{$\mathrm{R}$} & \multirow[b]{2}{*}{ R Square } & \multirow[b]{2}{*}{$\begin{array}{r}\text { Adjusted R } \\
\text { Square }\end{array}$} & \multirow{2}{*}{$\begin{array}{c}\text { Std. Error of } \\
\text { the } \\
\text { Estimate }\end{array}$} & \multicolumn{2}{|c|}{ Change Statistics } \\
\hline & & & & & $\begin{array}{l}\text { R Square } \\
\text { Change }\end{array}$ & F Change \\
\hline 1 & $.063^{\mathrm{a}}$ & .004 & -.007 & 4.79636 & .004 & .365 \\
\hline
\end{tabular}

Dari hasil perhitungan di atas, dapat diketahui bahwa koefesien determinasi ( $R$ Square) yaitu sebesar $0,04 \times 100 \%=4 \%$, artinya bahwa Kepuasan nasabah dipengaruhi oleh Kualitas pelayanan $\left(\mathrm{X}_{1}\right)$ sebesar 4\% dan sisanya sebesar 96\% merupakan faktor lain yang mempengaruhi Kepuasan nasabah yang tidak diteliti dalam penelitian ini. Berdasakan uji statistic diketahui bahwa bahwa hubungan kualitas pelayanan dan kepuasan nasabah adalah sebesar 0.061 bila dikaitkan dengan koefisian korelasi Rank Spearman (Riduwan, 2003;228), maka hubungan kualitas pelayanan dan kepuasan nasabah adalah sangat rendah sekali dan berdasarkan kriteria dapat diketahui bahwa $t_{\text {hitung }}<t_{\text {tabel }}$ yaitu $0604<1.667$ maka Ho diterima, artinya Kualitas pelayanan tidak berpengaruh signifikan secara parsial (individu) terhadap Kepuasan nasabah. Hal ini menunjukkan bahwa kepuasan nasabah tidak dipengaruhi secara parsial oleh kualitas pelayanan namun secara simulatan oleh kualitas pelayanan dan faktor lainnya. Seperti pendapat Irawan (2004 : 37), faktor - faktor yang pendorong kepuasan nasabah adalah sebagai berikut:

(1). Kualitas produk, pelanggan puas kalau setelah membeli dan menggunakan produk tersebut ternyata kualitas produknya baik.

(2). Harga, untuk pelanggan yang sensitive, biasanya harga murah adalah sumber kepuasan yang penting karena pelanggan akan mendapatkan value for money yang tinggi.

(3). Service quality, kepuasan terhadap kualitas pelayanan biasanya sulit ditiru. Kualitas pelayanan merupakan driver yang mempunyai banyak dimensi, salah satunya yang popular adalah SERVQUAL.

(4) Emotional Factor, pelanggan akan merasa puas (bangga) karena adanya emosional value yang diberikan oleh brand dari produk tersebut.

(5) Biaya dan kemudahan, pelanggan akan semakin puas apabila relative mudah, nyaman dan efisien dalam mendapatkan produk atau pelayanan.

\section{Kesimpulan}

Tingkat kualitas pelayanan di PT. BMRI unit Tanjung Siang terhadap nasabahnya cukup tinggi karena PT. BMRI Unit Tanjungsiang memiliki kemampuan dalam menunjukan kesistensinya kepada pihak eksternal. Penampilan dan kemampuan sarana dan prasarana fisik perusahaan yang dapat diandalkan dan keadaan lingkungan sekitarnya merupakan bukti nyata dari pelayanan yang diberikan oleh pemberi jasa. 


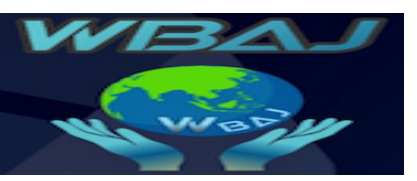

Volume 1 Issue 1, Juni 2019

http://ejournal.unsub.ac.id/index.php/bisnis

PT. BMRI Unit Tanjungsiang memiliki kemampuan untuk memberikan layanan sesuai dengan yang dijanjikan secara akurat dan terpercaya. PT. BMRI Unit Tanjungsiang memiliki suatu kebijakan untuk membantu memberikan pelayanan yang cepat dan tepat kepada nasabah, PT. BMRI Unit Tanjungsiang memiliki kemampuan, kesopanan, dan kemampuan karyawan perusahaan. PT. BMRI Unit Tanjungsiang memberikan perhatian yang tulus dan bersifat individual atau pribadi yang diberikan kepada para nasabah dengan berupaya memahami keinginan nasabah.

Tingkat kepuasan nasabah di PT. BMRI unit Tanjung Siang cukup tinggi dengan indikator nasabah PT. BMRI Unit Tanjungsiang telah merasa puas dengan produk layanan PT. BMRI dan nasabah merasa produk layanan PT. BMRI lebih baik dari produk layanan bank lainnya, adanya harapan (confirmattion of expectation) akan pelayanan yang berkualitas telah di dapat dari pelayanan PT.BMRI Unit Tanjungsiang dan sesuai dengan harapan nasabah dengan kinerja aktual produk perusahaan pada sejumlah atribut atau dimensi, adanya niat untuk selalau menggunakan produk layanan perbankan dari PT. BMRI Unit Tanjungsiang, adanya keediaan untuk merekomendasi (willingness to recommend) produk layanan PT. BMRI kepada teman atau keluarga menjadi ukuran yang penting untuk dianalisis dan ditindaklanjut, serta tidak ada rsaketidakpuasan nasabah (costumer dissatisfaction) terhadap pelayanan PT. BMRI Unit Tanjungsiang.

Pengaruh kualitas pelayanan secara variabel $\mathrm{x}$ tunggal (parsial) terhadap kepuasan nasabah di PT. BMRI unit Tanjung Siang tidak memiliki pengaruh namun bila kualitas pelayanan digabungkan dengan variabel $x$ (lainnya) memiliki pengaruh terhadap kepuasan nasabah.

\section{Referensi}

Abidin, Z.S., 2010, Kebijakan Publik, Jakarta, Yayasan Pancur Siwah.

Aprillia Fitriani. 2014. Hubungan Kualitas Pelayanan Terhadap Kepuasan Nasabah Pada PT. Bank BRI Syariah KCP Rawamangun. Program Studi Muamalat (Ekonomi Islam) Fakultas Syariah Dan Hukum Universitas Islam Negeri Syarif Hidayatullah Jakarta.

Az. Nasution, 2014, Hukum Perlindungan Konsumen di Indonesia, Bandung:PT. Citra Adiya Bakti

Catur, Rismiati.E. dan Ig. Bondan Suratno. 2001, Pemasaran Barang dan Jasa. Cetakan Pertama, Penerbit : Kanisius, Yogyakarta.

Denhardt, Janet V. and Denhardt, Robert B. 2003. The New Public Service: Serving, not. Steering. New York: M.E. Sharpe. Inc.

Fitri Madona. 2017. Pengaruh Kualitas Pelayanan Terhadap Kepuasan Nasabah Pada PT. Bank Syariah Mandiri Kantor Cabang 16 Ilir. Palembang Fakultas Ekonomi dan Bisnis Islam Universitas Islam Negeri Raden Fatah Palembang 


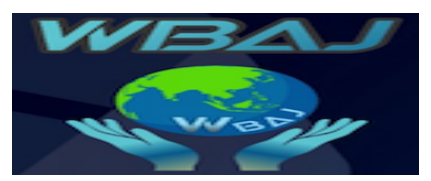

Volume 1 Issue 1, Juni 2019

http://ejournal.unsub.ac.id/index.php/bisnis

Hamdani, Lupioyandi. 2016. Manajemen Pemasaran Dan Jasa. edisi kedua. Jakarta: Salemba Empat

Irawan, H. 2004. Indonesian Customer Satisfaction: Membedah Strategi. Kepuasan Pelanggan Merek Pemenang ICSA. Jakarta : PT Alex Media Computindo

Kriyantono, Rachmat.2014. Teknik Praktis Riset Komunikasi. Jakarta : Kencana Prenadamedia Group

M. Nasution, 2005, Total Quality Managemen", PT Gramedia Pustaka Utama: Jakarta.

Pasolong, Harbani. 2017. Teori Administrasi Publik. Bandung: ALFABETA

Philip, Kotler. 2015. Manjajemen Pemasaran, Jilid I dan II terjemahan Benyamin Molar, Jakarta: PT. Indeks Kelompok Gramedia

Ratminto dan Atik Septi Winarsih. 2008. Manajemen pelayanan. Yogyakarta: Pustaka. Pelajar.

Silalahi, Ulber. 2009. Metode Penelitian Sosial. Bandung; PT. Refika Aditama.

Siregar, Syofian. 2015. Statistika Deskriptif Untuk Penelitian. Depok : Rajagrafindo Persada.

Sugiyono, Prof.Dr. 2014.Statistik Untuk Penelitian. Bandung : Alfabeta Bandung

Sugiyono. 2012. Metode Penelitian Kuantitatif Kualitatif dan RED. Bandung: Alfabeta.

Tjiptono, Fandy. 1996. Strategi Bisnis \& Manajemen. Yogyakarta: Andi

Tjiptono, Fandy. 1998. Pemasaran Jasa. Yogyakarta: Andi

Tjiptono, Fandy. 2014. Strategi Pemasaran. Edisi kedua.Yogyakarta: Andi. Torang, Syamsir. 2013. Organisasi dan Manajemen. ALFABETA: Bandung. Zeithaml, Valarie, A. Parasuraman and Leonard L. Berry. 1990. Devering Quality Service, New York: The Free Press. 